Feature Article

\title{
Social Geology and Landslide Disaster Risk Reduction in Sri Lanka
}

\author{
P. Jayasingha*
}

Landslide Research and Risk Management Division, National Building Research Orgnisation

\begin{abstract}
Landslide disaster risk reduction is presently a challenging task facing by Sri Lankan geologists. Increasing trend of population growth in Sri Lanka has adversely affected the stability of central highland due to various human activities. Among them establishment of human settlements and change in land use pattern have become a serious issue in triggering land instabilities in central highland of the country. National Building Research Oragnisation which is the main focal point in land slide disaster risk reduction in Sri Lanka has taken valuable and timely needed actions including preparation of landslide hazard zonation maps, early warnings and mitigations. Though the landslide is a geological phenomenon, it is highly interacted with human societies. Hence managing the issues arising with the landslide occurrence should be addressed with a sociological approach. This new approach is known as Socio Geological approach which is discussed here.
\end{abstract}

Key words: Landslide, Geology, Socio Geology, Social Geologist

\section{Introduction}

Overcoming the increasing threat and reducing the potential risk of landslide disasters are the present day challenges faced by the geologists working in the disaster management sector of Sri Lanka. Though the landslide occurrence in the country is a natural hazard triggered by natural factors such as unusually cumulating rainfall, increasing density of vegetation cover and accumulating weight of over lying soil blanket (Rathnayake and Herath, 2005; Dissanayake and Rupasingha, 2007; Blackenburg et al., 2007), recent observations have shown that the human intervention in triggering has dramatically been trending up. In reasoning the trend of human intervenes, the growth of population (Figure 1) becomes the top due to result of it which has caused many changes in land use pattern of the country.

Utilization of lands in central highland is characterized by establishment of human settlements, construction of new roads and road widening, setting up of hydropower schemes and cultivating economic crops and vegetables. Blocking out of large lands for selling in catering with the demand for human settlements is increasingly dominated. Hence, diminishing of large land owners is one of the prominent issues arisen with the population growth. The well noted recent observations in the central highland of the country are the blocking out of state sector lands and promoting medium and small scale plantations that have led to degrade the hilly environment (Mungai et al., 2004). And also, it is clearly evidenced that the land clearing including road cuts which triggers soil erosion and unnecessary water infiltration has initiated unstable slopes in hilly areas (Herath et al., 2014).

"Correspondence: jpathmak@gmail.com

Tel: +94718433319

ISSN 2235-9370 Print/ISSN 2235-9362 Online (C) University of Sri Jayewardenepura 
Hence this has caused frequent mass movements and cutting failures during the recent monsoon and extreme weather conditions (Figure 2).

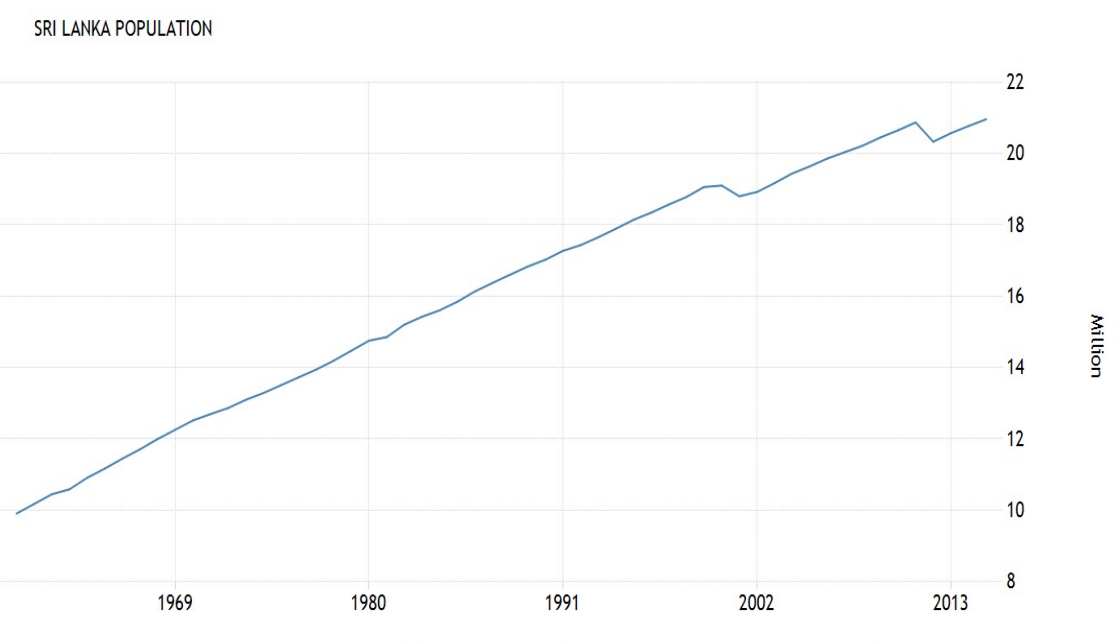

SOURCE: WWW.TRADINGECONOMICS.COM I DEPARTMENT OF CENSUS AND STATISTICS - SRI LANKA

Figure 1: Trend of population growth in Sri Lanka.

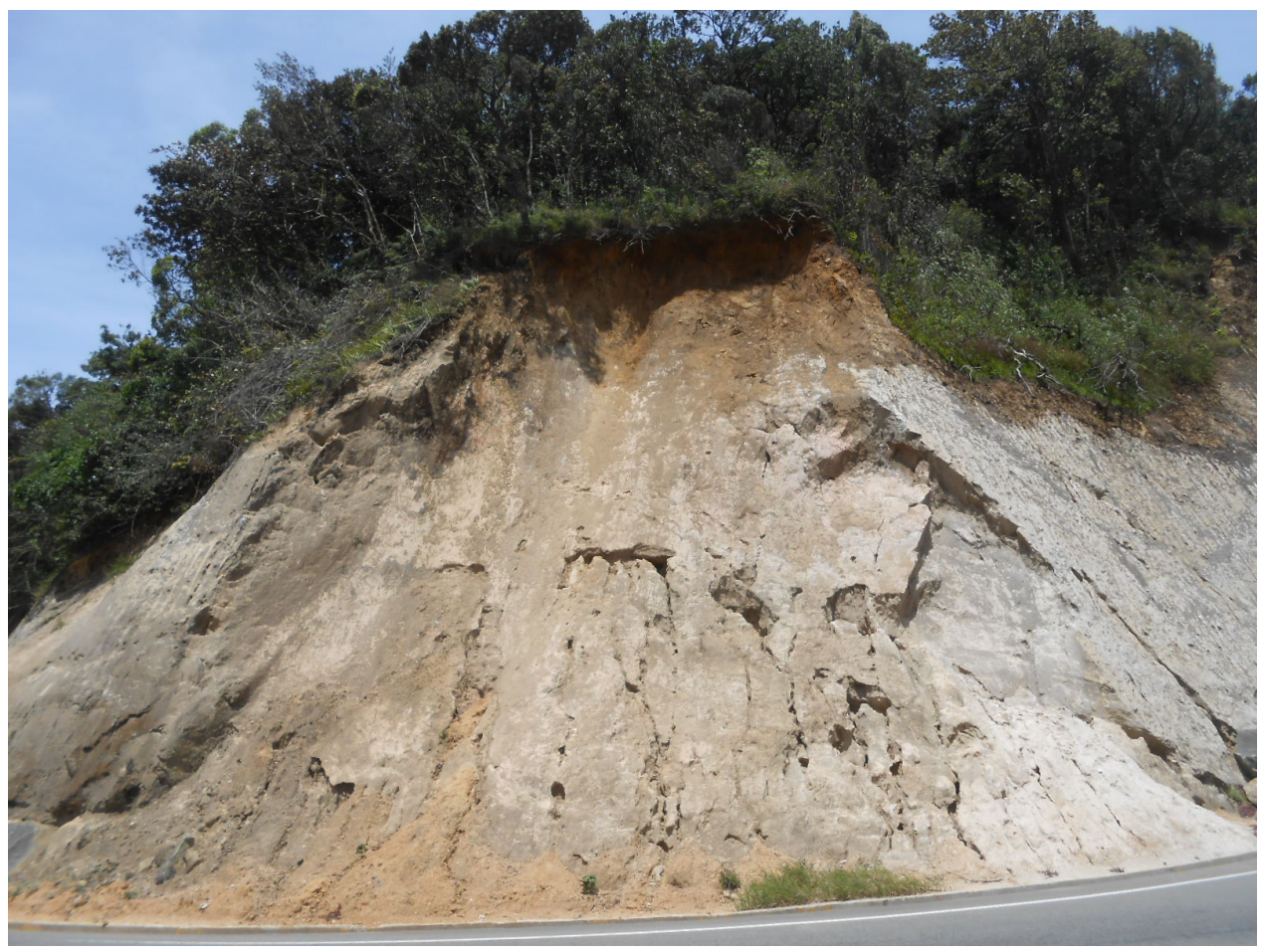

Figure 2: Cutting failure at Hakgala due to road cuts. 
The population of the central highland accounts for $30 \%$ of the total populations and the central highland which covers $20 \%$ of the total land area of the country is divided into 12 districts where most places are prone to landslide hazard (Figure 3). Hence it is obvious that increase of the population in the central highland of Sri Lanka which leads to new establishment of human settlements and expanding of urbanized areas and road network escalates the landslide vulnerability, hence to accelerate the risk of landslide disaster. Loss of lives (Figure 4), abandoning of settlements and economic grounds and destroying infrastructure facilities which are resulted by landslide disasters has led to various social and economic issues in the country (Kjekstad and Highland, 2009).

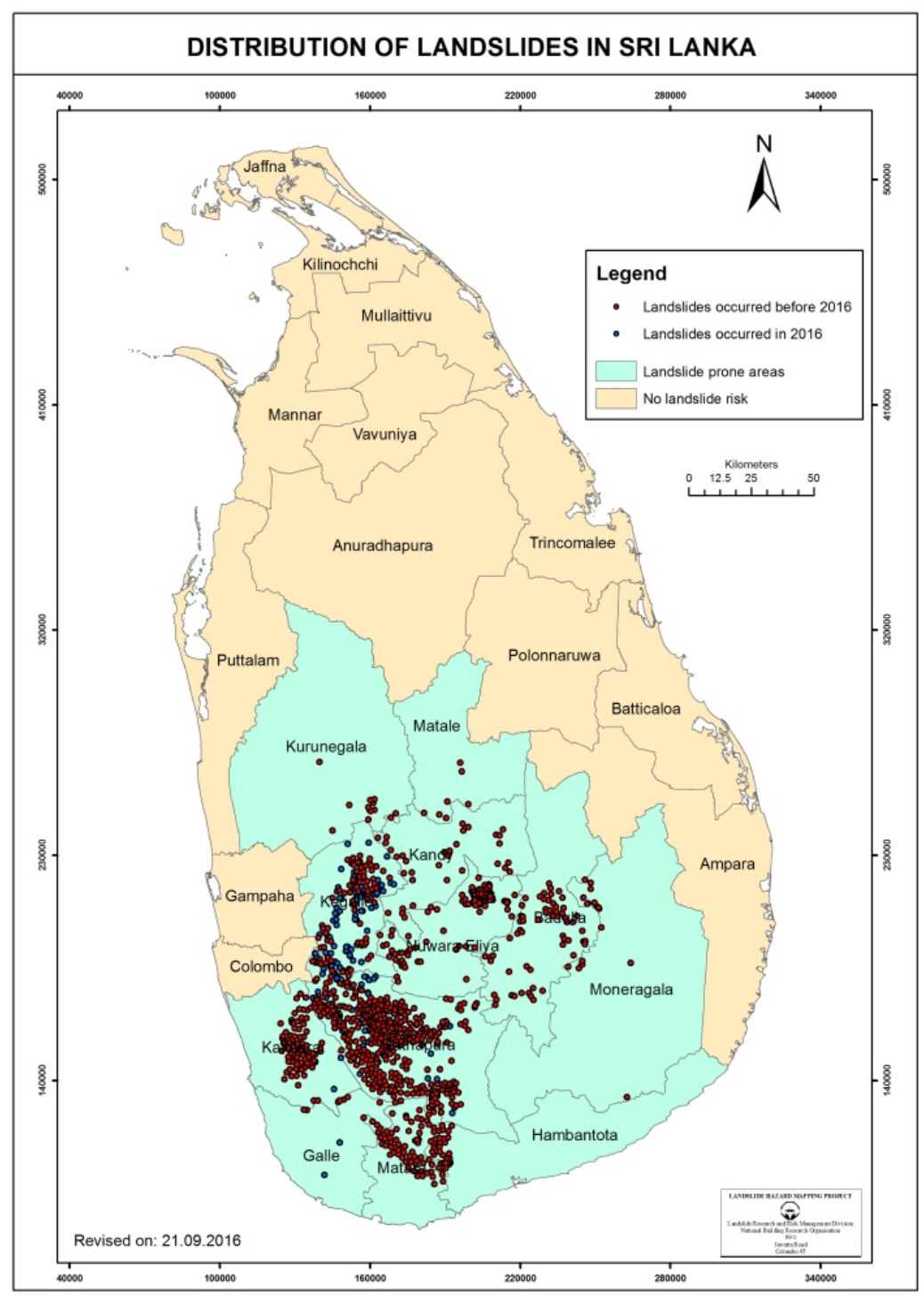

Figure 3: Distribution of occurred landslides in Sri Lanka. 


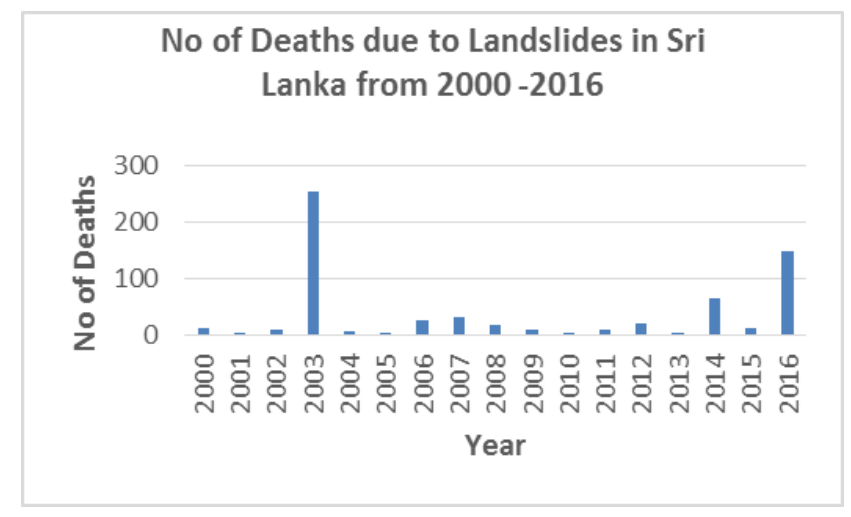

Figure 4: Number of deaths due to landslide hazard in Sri Lanka (2000-2016).

In comparison, the social and economic issues arisen from landslide disasters have become major burning issues in the country (Katupotha, 1999). It can be inferred that those social and economic issues have mainly been resulted due to lack of awareness on landslide which is one of the worst geo-hazards in Sri Lanka and the post disaster consequences. The lack of awareness in landslide hazard can seriously affect disaster management program. Hence understanding the nature and the behavior of landslide occurrences in Sri Lanka should essentially be needed by both potential victims and personals of disaster management. Such awareness on landslide hazard greatly influences a proper and systematic approach in different stages of landslide disaster risk reduction program such as pre-disaster stages, response and post disaster stage. Hence, disseminating the knowledge on landslide geo hazard to the community in reducing the sociological stress can be considered as a part of present day challenges facing by the geologists in landslide disaster context of the country.

Dealing with social issues due to geological phenomenon such as landslide and tsunami or geological resources such as water, coal and petroleum is discussed in "Social Geology" which is a naval concept developing in the world (Mata- Perello, 2012). Social Geology, the new discipline of geology, is a timely concept which can be used to address the sociological issues arisen from landslide disaster in Sri Lanka (Jayasingha et al., 2016). This paper describes the application of social geology in landslide disaster risk reduction and the essential steps of social geology to be applied in landslide disaster risk reduction.

\section{Landslide Disaster Risk Reduction in Sri Lanka}

The main focal point of landslide disaster risk reduction in Sri Lanka is the National Building Research Organisation (NBRO) established in 1985. Considering her 30 years of contribution and experience, NBRO has been accepted and authorized by the government to be the mandatory national institute for landslide disaster risk reduction in the country. NBRO was authorized to regulate any kind of development activity within landslide prone districts by a government circular (NBRO/2011/1). Hence NBRO is powered to investigate and assess each and every site specific landslide risk and issue technical recommendations in reducing landslide risk.

NBRO has strong connections and jointly works with Disaster Management Centre (DMC), Department of Meteorology, Department of Irrigation and Local Authorities of Sri Lanka in landslide disaster risk reduction. 
The landslide disaster risk reduction program in Sri Lanka is a cyclic process as given in the figure 5. It consists mainly of three stages as given as (i) pre-disaster stage, (ii) response stage and (iii) post disaster stage. Risk assessment, prevention/mitigation and preparedness are the main activities of pre-disaster stage. Soon after a landslide disaster is occurred, response stage comes in to action in rescuing and securing mainly human life and related infrastructures. Hence evacuation, rescue activities, immediate assistance for affected communities, assessment of damages and restorations of infrastructures are carried out. Post disaster stage includes somewhat long term activities such as reconstruction, economic and social recovery and ongoing developments activities. In addition, again risk assessment, prevention and mitigation activities are also considered in post disaster stage.

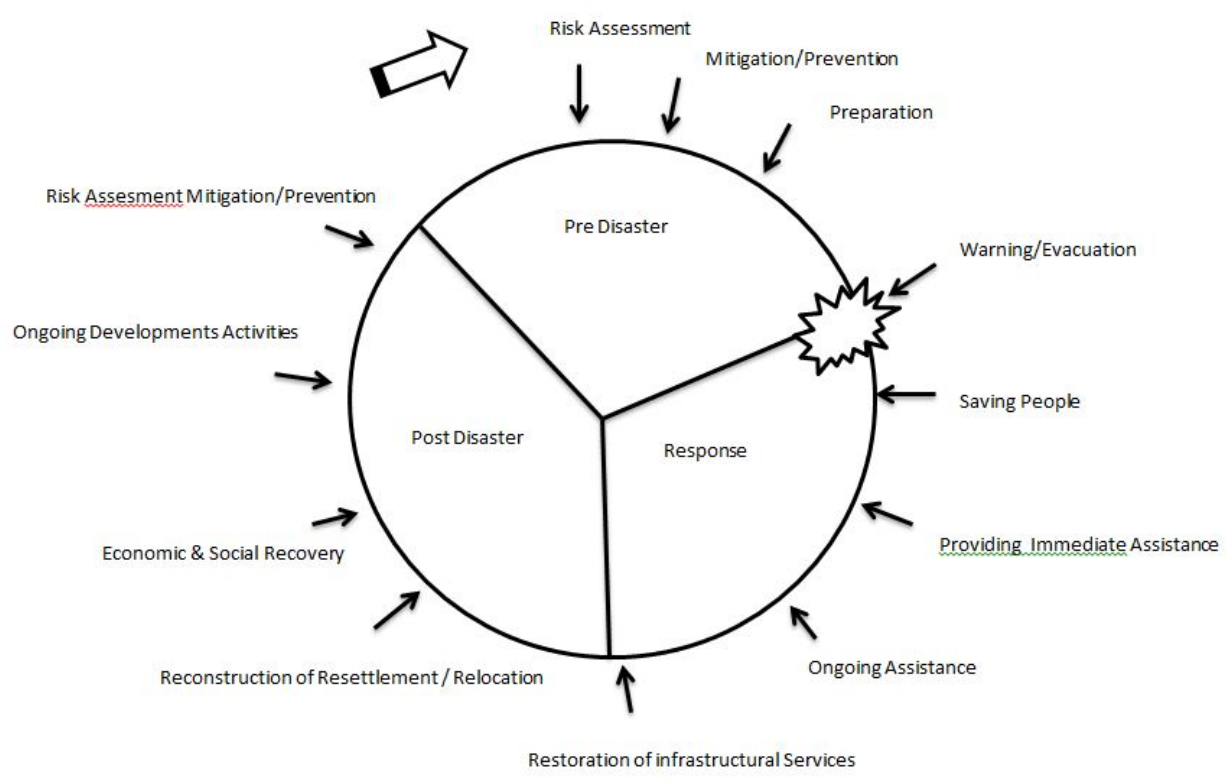

Figure 5: Landslide Disaster Risk Reduction Process in Sri Lanka.

In Sri Lanka, preparation of hazard zonation maps, setting up of an early warning system based on automated rain gauges, establishment of low enforcements, conducting community awareness and taking structural mitigatory measures are the kind of preparedness activities of pre disaster stage presently carried out. Issuing early warning considering real time rainfall data can be considered as a kind of prevention activity practiced in Sri Lanka. The stage of response after a landslide disaster occurred is the most crucial and complicated stage where various community involvements should strongly be needed specially in rescuing, evacuating, temporary resettling and facilitating activities.

\section{Geological Nature of Landslides in Sri Lanka}

According to the geology of Sri Lanka (Figure 3), the central highland is composed of Proterozoic high grade metamorphic rocks (Cooray, 1994). All most all the landslides occurred and the potential grounds have been resulted by prolonged weathering of those rocks. Most of the rocks in those metamorphic terrains are mineralogically composed of feldspar and flaky minerals such as mica and they are structurally weaken due to various 
weak zones such as foliation, joints and fractures (Figure 4). Due to its locality that close to the equator, Sri Lanka is always experiencing the impact of tropical climate. Hence the rocks of the central highland are undergoing high rate of weathering that thicken the overlying soil blanket. Therefore it can be considered that the nature of geology is vital factor of triggering, though the most landslides occurred in Sri Lanka were hydrometeorologically induced.

Differential weathering of rocks specially due to geological structures in the central highland causes different geomorphologies (Romer, 2007; Phillips, 2005). Hence steep slopes are common in the central highland (Figure 5). It is obvious that the thickening of soil profiles is high in wet zone of in the central highland rather than that of in dry zone. The thick soil profiles in steep slopes tend to form landslide potential grounds in the central highland of Sri Lanka.

Considering the soil characteristics, it is important to understand the types of soils in landslides and potential grounds. There are two soil types that can be identified as residual soil resulted from weathering of metamorphic rocks (Fookes, 1997) and colluvial soil (Figure 6) resulted from short distance transportation of residual soil (Nagarjan, 2000). The areas of landslide occurred are characterized by colluvial soil, but potential ground may consists of both.

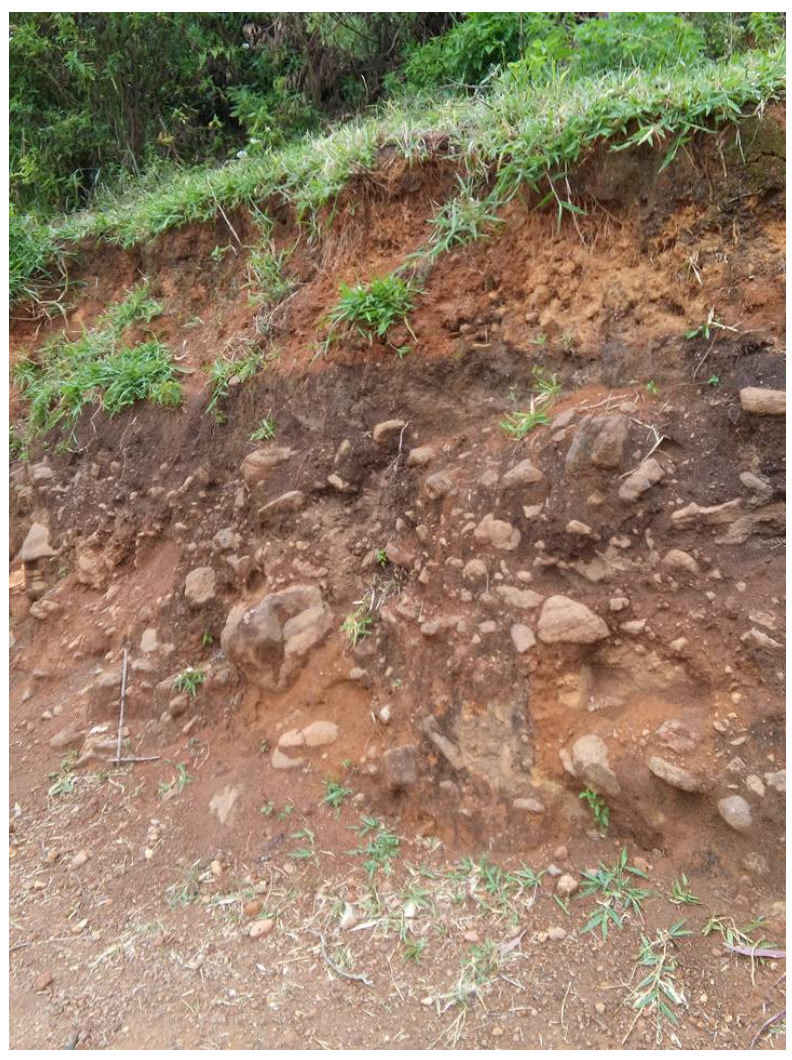

Figure 6: A colluvial soil profile shows two stages of deposition of transported materials.

Due to the rapid growth of population most of the slope in the central highland have been touched and disturbed. Poor consideration and lack of knowledge of geology, geomorphology and geological hazards, soil cuts for constructing buildings and new roads 
and road widening have been extensively made in the central highlands. Hence some stable lands and stabilized paleo landslides have presently been activated.

\section{The Crucial Activities to be addressed by Social Geology}

After one and half decades of landslide disaster risk reduction process established in Sri Lanka, it can be seen that many components of it are yet to be developed (Table 1). Considering the social aspects of the landslide disaster risk reduction program, the PreDisaster Stage is critical and a systematic approach is needed to minimize those social aspects that are predictable to happen after a disaster. However more attention and caring should be needed in Response Stage, because highly sensitive social impacts which are sometime immediate are identified. The social issues during the Post Disaster stage is severely complicated due to many reasons. If the recovery process is not properly planned and implemented, affected communities are suffered for a long time and most of the phases of social life of affected people are changed. Following activities carried out in Sri Lankan landslide disaster risk redun process can be identified as crucial activities which largely impact on sociological sphere.

Table 1: Summary of some of the components in disaster management program which are yet to developed.

\begin{tabular}{|c|c|c|c|}
\hline Stage & Components to be further developed & Nature of responsibility & $\begin{array}{l}\text { Affected } \\
\text { Sphere }\end{array}$ \\
\hline \multirow[t]{6}{*}{$\begin{array}{l}\text { Pre- } \\
\text { Disaster }\end{array}$} & $\begin{array}{l}\text { Identification of local hazard zones and } \\
\text { potential landslides }\end{array}$ & Geological & Social \\
\hline & $\begin{array}{l}\text { Dissemination of information on potential } \\
\text { landslides and vulnerable areas }\end{array}$ & Social and geological & Social \\
\hline & $\begin{array}{l}\text { Dissemination of information on nature } \\
\text { and behaviour of landslides }\end{array}$ & Geological and social & Social \\
\hline & $\begin{array}{l}\text { Issuing localized early warnings among } \\
\text { localized and regional communities }\end{array}$ & $\begin{array}{l}\text { Geological, social and } \\
\text { administrative }\end{array}$ & Social \\
\hline & Establishment of low enforcements & $\begin{array}{l}\text { Geological, } \\
\text { administrative and legal }\end{array}$ & Social \\
\hline & Setting up of evacuation roots & $\begin{array}{l}\text { Administrative, } \\
\text { geological and social }\end{array}$ & Social \\
\hline \multirow[t]{2}{*}{ Response } & Evacuation & $\begin{array}{l}\text { Geological, } \\
\text { Administrative and } \\
\text { social }\end{array}$ & Social \\
\hline & Rescue & $\begin{array}{l}\text { Administrative and } \\
\text { social }\end{array}$ & Social \\
\hline
\end{tabular}


Establishment of temporary shelters in previously identified and selected safe locations

Facilitating during disaster time and post disaster period

Administrative and social

Post
Administrative and

social
Identification of suitable locations for establishing permanent settlements
Social

Social

Social

administrative

Identification of potential hazard zones and issuing early warning have considerably been improved during the last decades in Sri Lanka due to landslide zonation mapping program and rainfall based regional early warning system established by NBRO. The developed 1:50 000 landslide hazard zonation maps give excellent coverage on potential hazard zones in regional scale (Figure 7). Hence the risk or the vulnerability of landslide disaster for a given location can easily be assessed by using the information given in the landslide hazard zonation maps. Developing a risk is largely depend on behaviour and activities of humans by which land use pattern is continuously changed and it is highly temporal. Hence developing permanent landslide risk map for a particular area is sometime useless. Developing local hazard zonation maps (1:5000) are time and resource consuming activity where mostly geological knowledge and social /community support have to be involved. Extracting traditional knowledge on local geology must essentially be included in those maps which can later be useful in defining evacuation roots and finding safe grounds.

The early warning system developed by NBRO is entirely based on real time rain fall data gathered from automated rain gauges installed in 160 locations that covers the central highland of the country. In addition manual rain gauges (more than 2,000) have been given to the communities in previously identified vulnerable areas. Alert, warning and evacuation are given by three different threshold limits set as $75 \mathrm{~mm}, 100 \mathrm{~mm}$ and $150 \mathrm{~mm}$ of rain fall during a three days period (Liyanage et al,. 2016). Based on the real time data, vulnerable and risk areas for landslide are forecast. More importantly, the need of localized early warning systems have recently been identified. As presently experiencing, the local climatic pattern can be deviated from the regional pattern and hence issuing early warnings can sometime be problematic and contradicted. Therefore, establishment of localized early warning systems in reduction of landslide risk at local level should essentially be developed soon and it can further be stressed that involvement of vulnerable communities must be vital. 


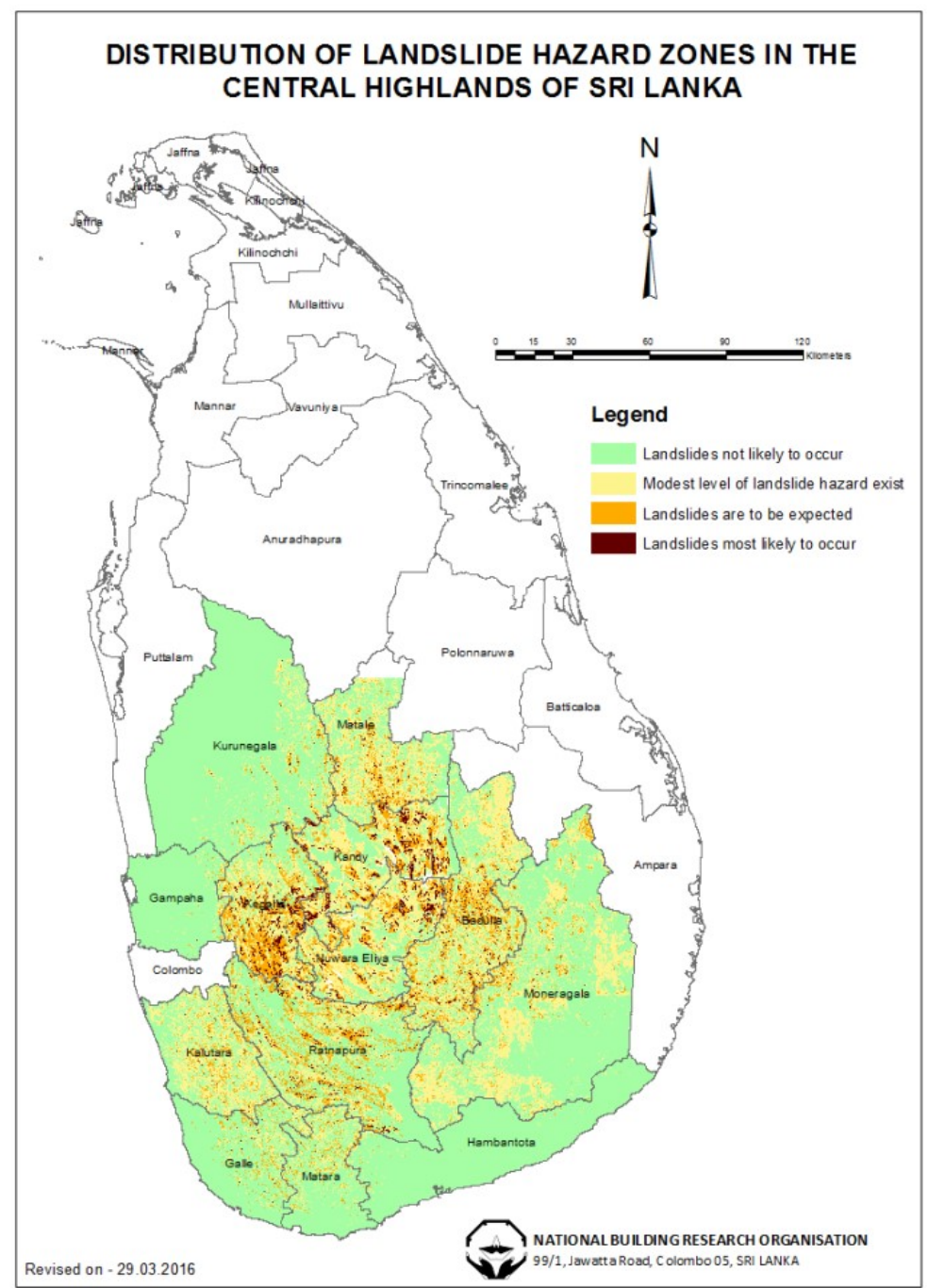

Figure 7: Distribution of hazard zones of the central highland Sri Lanka.

Setting up of evacuation routes in potential landslide areas is one of the critical steps which should be well planned before come to evacuation phase. Hence successful evacuation is totally depend on secured and undisturbed routes. In defining of evacuation routes which are entirely site specific, resident knowledge in geology and geomorphology is needed. Not only that, native information and traditional knowledge should be merged with the resident knowledge of geology, geomorphology, landslide hazard phenomenon and triggering factors. Also identification and selection of safe grounds for temporary settlements is largely helped from information given by local community (Figure 8). 

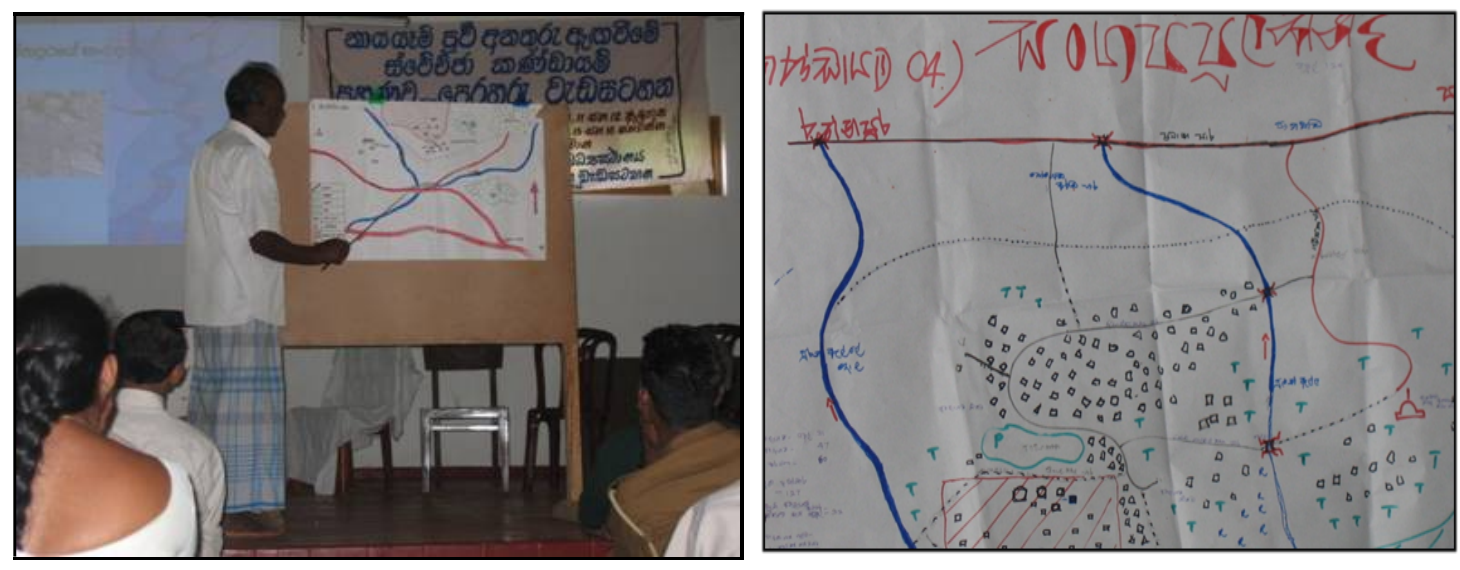

Figure 8: Setting up of evacuation routes with the involvement of community.

Though decision making on identification of communities to be permanently evacuated and abandoning of public places such as schools and hospitals are mainly based on potential risk of landslide disaster and landslide hazard geology, many social geological factors including needs of community and phase changes in day today activities of affected communities must be taken into consideration. No any mitigation in high hazard zones is considered by NBRO and hence permanent evacuation is recommended. But if a particular community is located in a potential or developing or partly occurred landslide area of medium hazard and low hazard zones, mitigation program is proposed considering the actual needs of community and it is implemented irrespective of cost of mitigation. Hence it is well understood that social aspects are the prime concern in this regard.

\section{Socio Geological Approach in Landslide Disaster Risk Reduction}

Any social aspects related to landslide disaster risk reduction can be discussed under discipline of "Social Geology". Hence all of them should be considered and addressed sociogeologically to improve the present day lacks and gaps in landslide disaster risk reduction process in Sri Lanka. The proposed social geological approach here points out the essential role of geologists in securing and saving the human lives who are to be affected by landslide hazards. The vital requirement of dissemination of geoscientific knowledge among different social groups including the communities at grass root levels is clearly understood and sharing the knowledge among those groups is highly encouraged in this approach.

Building up of "Socio-Geological Network" is the prime concern in the proposed social geological approach. Hence, among the various stake holders in landslide disaster risk reduction process, Geologists and Vulnerable/Affected Communities are considered as the main interacting parties. Five main aspects of the proposed approach are also identified. They are; Identification, Awareness, Application, Action and Exchange (Table). Networking all the stakeholders and various social groups in potential landslide areas with a central governing body of which the core is consists of geologists keeps the connectivity. The central governing body, social media, emergency services and conducting awareness are the main pillars of the socio-geological network (Jaysingha et al., 2015). Development of a mechanism for dissemination of real time data and information is essential and rapid dissemination will strengthen the connectivity of the stakeholders in the socio-geological network. 
Table 2: Main aspects of social geology in landslide disaster risk reduction.

\begin{tabular}{|c|c|c|}
\hline Aspects & Description & Involvements \\
\hline Identification & $\begin{array}{l}\text { Identification of state and geological nature of landslide } \\
\text { disaster and assessing potential risk. } \\
\text { Identification of potential or affected communities and } \\
\text { gathering all site specific social geological information }\end{array}$ & $\begin{array}{l}\text { Geologists, } \\
\text { Social } \\
\text { Geologists, } \\
\text { Engineering } \\
\text { Geologists } \\
\text { Geotechnical } \\
\text { Engineers } \\
\text { Civil Engineers }\end{array}$ \\
\hline Awareness & $\begin{array}{l}\text { Aware communities engaged with landslide disaster specially } \\
\text { on geology, geo hazards, hazard zonation maps, rescue, } \\
\text { evacuation, mitigation program, early warnings etc. } \\
\text { Extracting and sharing local and traditional knowledge related } \\
\text { to landslide disaster. } \\
\text { Aware and defining role of each parties and other stakeholders } \\
\text { engaged with landslide disaster. }\end{array}$ & $\begin{array}{l}\text { Social } \\
\text { Geologists, } \\
\text { Geologists, } \\
\text { Public } \\
\text { communities } \\
\text { Administrators } \\
\text { Stakeholders }\end{array}$ \\
\hline Action & $\begin{array}{l}\text { Forming a socio-geological network } \\
\text { Defining all activities in landslide disaster risk reduction } \\
\text { including development of mechanism for dissemination of real } \\
\text { time data and information. } \\
\text { Finally defining social geological risk reduction plan }\end{array}$ & $\begin{array}{l}\text { Social } \\
\text { Geologists, } \\
\text { Geologists, } \\
\text { Engineers } \\
\text { Public } \\
\text { Communities } \\
\text { Administrators } \\
\text { All other } \\
\text { stakeholders }\end{array}$ \\
\hline Application & $\begin{array}{l}\text { Application of social geological risk reduction plan to a } \\
\text { particular landslide disaster (potential or occurred) }\end{array}$ & $\begin{array}{l}\text { Two main } \\
\text { interacting } \\
\text { parties } \\
\text { All other } \\
\text { stakeholders. }\end{array}$ \\
\hline Exchange & $\begin{array}{l}\text { Exchanging data gathered from the field such as rainfall, } \\
\text { movements of soil mass etc and final outcomes from the crucial } \\
\text { analysis of field/raw data with all the stakeholders such as early } \\
\text { warnings. }\end{array}$ & $\begin{array}{l}\text { Two main } \\
\text { interacting } \\
\text { parties } \\
\text { Central } \\
\text { Governing body }\end{array}$ \\
\hline
\end{tabular}




\section{Conclusions}

Landslide disaster risk reduction has become an essential part of securing human life in Sri Lanka today mainly due to enhanced anthropogenic activities which has created many issues related to land instability. Since the landslide occurrence is a geo hazard, which creates sudden disasters and from which many social groups are affected, role of geologists in landslide disaster risk reduction is vital. Social aspects related to such geo hazards are discussed under new discipline called "Social Geology". The social issues arisen with landslide geo hazard is quite complicated and need of systematic approach is presently understood. The social geological approach proposed here for smooth functioning of landslide disaster risk reduction program is characterized by two main interacting parties identified as Geologists and Potential/Affected Community, a Central Governing Body and a Socio-Geological Network. The central governing body of which the core consists of geologist keeps the connectivity with all stake holders and other engaged parties. Identification, Awareness, Action, Application and Exchange are the main steps to be followed in social geological risk reduction plan. Correct establishment and proper functioning of socio-geological network will greatly influence on landslide disaster rick reduction process in Sri Lanka.

\section{Reference}

Blackenburg, F.V., Hewawasam, T. and Kubik, P.W., 2004. Cosmogenic nuclide evidence for low weathering and denudation in the wet, tropical highlands of Sri Lanka. Journal of geophysical research; earth surface. 109 (F3).

Cooray, P.G., 1994. The precambrian of Sri Lanka: a historical review. Precambrian Research 66, 3-18.

Dissanayake, C.B. and Rupasingha, M., 1996. Environmental impact of mining, erosion and sedimentation in Sri Lanka. International Journal of Environmental Studies. 51(1).

Fookes, P.G., 1997. Tropical Residual Soil. A geological society engineering group working party revised report. The Geological society, London.

Herath, M.J.M.K., Kodagoda, S.S.I. and Dias, A.A.V., 2014. Shallow Modes of Slope Failure in Road Earth Cuttings in Sri Lanka. Landslide Science for a Safer Geoenvironment. pp 51-58.

Jayasingha, P., Bandara, K.N., Bandara, R.M.S. and Jayathissa, G., 2016. Social aspects in landslide disaster risk reduction in Sri Lanka. Proceedings of the 32nd Technical Sessions of Geological Society of Sri Lanka Published Online - 26th February 2016. pp25.

Katupotha, J., 1999. Effect of landslide on society and economy in Sri Lanka. 2nd International conference on Landslides, slop stability and the safety of infrastructures.27-28th July, 1999.

Kjekstad, O. and Highland, L., 2009. Economic and Social Impacts of Landslides. Landslides - Disaster Risk Reduction. pp 573-587.

Liaynage, U.L.N.I., Bandara, R.M.S., Indrathilake, H.M.L. and Iwasaki, I., 2016. Threshold limits on slope disaster events in May, 2016. Case study from Kegalle district in Sri Lanka. NBRO international symposium 2016. pp 164-168.

Mata-Perello, J.M., Mata-Lleonart, R., Vintro-Sanchez, C. and Restrepo-Martinez, C., 2012. Social Geology; A new perspective in geology. Dyna. 79(171) pp. 158-16. 
Mungai, D.N., Ongb, C.K., Kitemec, B., Elkaduwad, W. and Sakthivadiveld, R. 2004. Lessons from two long-term hydrological studies in Kenya and Sri Lanka. Agriculture, Ecosystems \& Environment. 104(1), pp 135-143.

Nagarajan, R., Roy, A., Vinod Kumar, R., Mukherjee, A. and Khire, M.V., 2000. Landslide hazard susceptibility mapping based on terrain and climatic factors for tropical monsoon regions. Bull Eng Geol Env 58: 275.

Philips, J. D., 2005. Weathering instability and landscape evolution. Geomorphology. 67 (12) pp 255-272.

Rathnayake, U. and Herath, S., 2005. Changing rainfall and its impact on landslides in Sri Lanka. Journal of mountain science. 2(3), pp 218-224.

Romer, W., 2007. Differential weathering and erosion in an inselberg landscape in southern Zimbabwe: A morphometric study and some notes on factors influencing the longterm development of inselbergs. Geomorphology. 86 (3-4) pp 349-368. 